Original Research Paper

\title{
Monitoring Land Use and Land Cover Effects on Water Quality in Cheung Ek Lake using ASTER Images
}

\author{
${ }^{1}$ Nara Im, ${ }^{1}$ Kensuke Kawamura, ${ }^{1,2}$ Endan Suwandana and ${ }^{3}$ Yuji Sakuno \\ ${ }^{I}$ Graduate School for International Development and Cooperation, Hiroshima University, Higashi-Hiroshima, Japan \\ ${ }^{2}$ Education and Training Center of Banten Province, Banten, Indonesia \\ ${ }^{3}$ Institute of Engineering, Hiroshima University, Higashi-Hiroshima, Japan
}

Article history

Received: 25-08-2014

Revised: 04-09-2014

Accepted: 25-03-2015

Corresponding Author:

Nara Im

Graduate School for International Development and Cooperation, Hiroshima University, HigashiHiroshima, Japan

Email: naraenv@gmail.com

\begin{abstract}
Cheung Ek Lake is the biggest natural treatment plant for nearly $80 \%$ of wastewater and storm-water from Phnom Penh city. Land Use and Land Cover (LULC) changes of the lake and its catchment area could deteriorate capacity of the lake in purifying wastewater and affect to its water quality. The study aims to assess the relationship between LULC changes and water quality using ASTER images with field observations. Three pairs of temporal ASTER images in 2002, 2009 and 2011 acquired in dry season were used to make LULC map with five classes: (1) Urban or built-up areas, (2) rangeland, (3) agricultural land, (4) water bodies and (5) barren land, using Maximum Likelihood (ML) classification method. Post-classification comparison was chosen to study changes from 2002 to 2009 and from 2009 to 2011. The water quality data of the Ministry of Environment from 2000 to 2013 were used to study water quality change. Spatial distribution of water quality parameters including total phosphorus, total nitrogen, chemical oxygen demand, five-day biochemical oxygen demand, total suspended solids and chlorophyll- $a$ was observed in the rainy and dry seasons in 2012 and 2013, respectively. The results showed that ML gave moderate level with overall accuracy of around $60 \%$ and Kappa coefficient of around 0.48 for classification images in all three dates. Also, some significant change were happened between 2002 and 2011; rangeland decreased by approximately $22 \%$, while agricultural land and urban or built-up areas increased by more than 2 and $16 \%$, respectively. In addition to the downward trend of water quality status changes recorded by the Ministry of Environment from 2000 to 2013, the spatial distribution maps revealed that wastewater from the city was the main source of water quality deterioration. These results might be suggested that LULC changes of the lake's catchment area appeared to have negative effects on water quality of the lake.
\end{abstract}

Keywords: Cambodia, Remote Sensing, Urbanization, Water Environment

\section{Introduction}

Phnom Penh, the capital city of Cambodia, has been facing rapid population growth that the government concerns about. The population has been growing from less than one million in 1998 to more than 1.4 million in 2008 (NIS, 1998-2008) and to nearly 1.6 million in 2010 (Doyle, 2012). The area of the city was also revised and expanded from $375.43 \mathrm{~km}^{2}$ in 2005 to a double size of
$678.46 \mathrm{~km}^{2}$ in $2010(\mathrm{PPCH}, 2010)$. The population growth has resulted in unmanageable changes of Land Use and Land Cover (LULC) in the city and periareas (Doyle, 2012) that largely occurs in the suburbs of the city where agricultural lands, wetlands, streams and ponds have been developed through building projects such as new satellite towns, apartments and industrial zones.

Cheung Ek Lake is the largest flood and wastewaterabsorbing wetland for the city. Almost the whole core 
city's zone, approximately $25.73 \mathrm{~km}^{2}$, is the catchment area of this lake and nearly $80 \%$ of total wastewater from this catchment is drained into the lake (Van der Hoek et al., 2005; Khov et al., 2005). The wastewater are sewages from residents and industrial effluents from factories dealing with battery fabric and repair, paint manufacture, zinc and metal products, pulp and paper, textiles, plastics (Muong, 2004). The lake is also significantly used as a natural treatment plant for all the wastewater and it is found that the lake is efficient in purifying wastewater before it flows into the Bassac River (Sovann et al., 2011; Irvine and Koottatep, 2010). Therefore, the changes of Cheung Ek Lake and its surrounding areas are a great concern, since these changes might negatively affect the lake's capacity for purifying wastewater, its water quality and particularly the water quality of the Bassac River (Chea et al., 2010; Khov et al., 2007).

LULC and LULC change are important drivers of change of water quality and satellite remote sensing is widely used to study the relationship between LULC and water quality. For example, Zhang et al. (2009) used MODIS and MERIS to investigate the impacts of LULC change on water quality in Pearl River estuary and Hong Kong's coast; Forney et al. (2001) studied land use change and effects on water quality in lake Tahoe basin in Nevada and California by using Digital Orthophoto Quadrangles (DOQ) and IKONOS satellite imagery; and Sobonn et al. (2007) assessed the effects of LULC on water quality of tonle sap lake in Cambodia with Landsat 7 ETM+ and MODIS satellite imageries.
However, little information is available on how affect such rapid urbanization of Phnom Penh city on water quality in Cheung Ek Lake's catchment area. Therefore, this study aims to monitor the relationship between LULC change of Cheung Ek Lake's catchment area and the water quality of the lake using satellite data with ground observation.

\section{Materials and Methods}

\section{Study Area}

The study was conducted on Cheung Ek Lake and its catchment area $\left(99.48 \mathrm{~km}^{2}\right)$, located at the south of

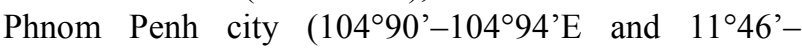
$\left.11^{\circ} 53^{\prime} \mathrm{N}\right)$ (Fig. 1). The lake's surface area changes from approximately 1,300 to 3,000 ha in the dry and rainy seasons, respectively, with an average depth of 0.5-1.5 m in the dry season and 7-9 $\mathrm{m}$ in the rainy season. The average annual rainfall is $1,440 \mathrm{~mm}$. The elevation is around $10 \mathrm{~m}$ above sea level.

\section{Terra ASTER Images}

Terra satellite on-board ASTER Level 1B imageries acquired on the 20 February 2002, 22 January 2009 and 28 January 2011 with cloud cover less than $10 \%$ were used. Only Visible to Near Infrared bands (VNIR) (bands $1-3 \mathrm{~N} ; 0.52-0.86 \mu \mathrm{m}$ ) were used owing to the anomalous saturation of values and anomalous striping of Shortwave Infrared (SWIR) bands.

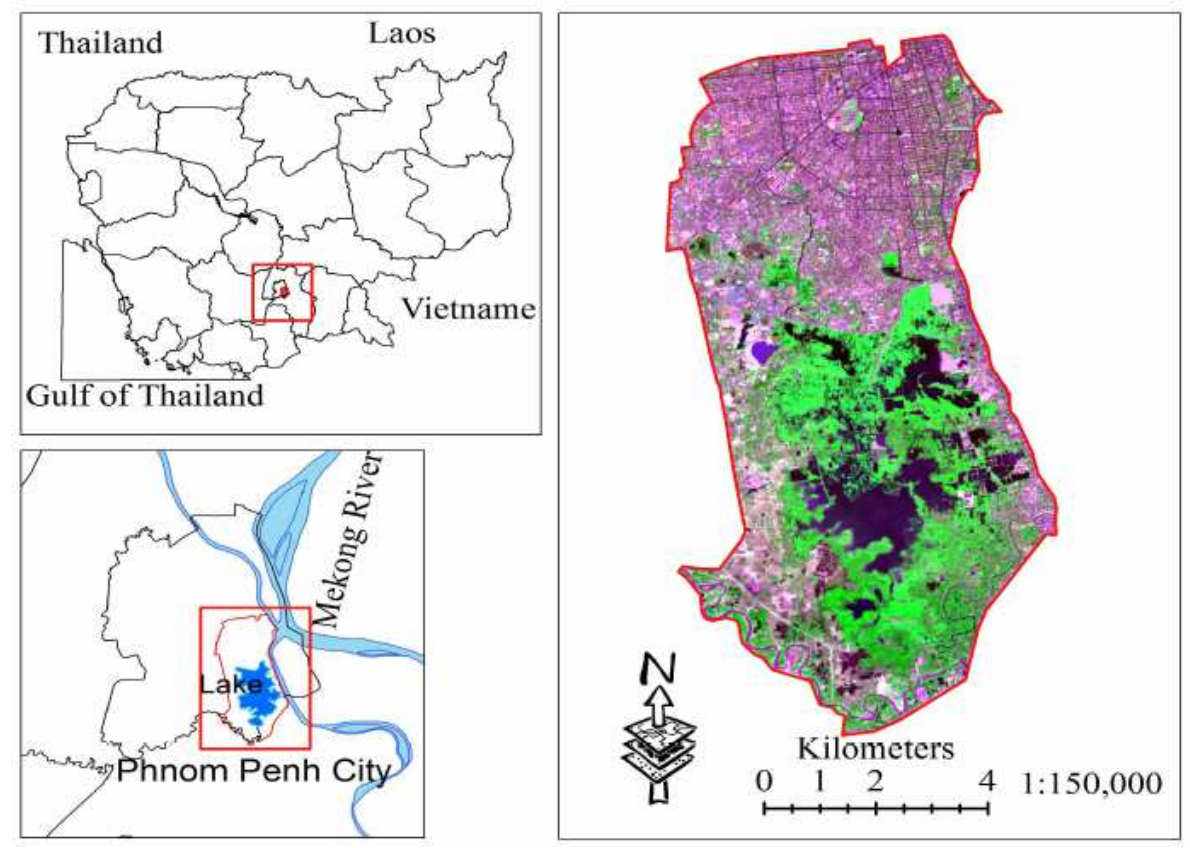

Fig. 1. Location of study area of Phnom Penh city (bottom left) and the Region Of Interest (ROI) of the ASTER image processing (right) 
The images were firstly registered to Universal Transverse Mercator (UTM) projection, World Geodetic System 1984 (WGS84) datum, zone 48N. Secondly, the Digital Number (DN) value of images was converted to Top-Of-Atmosphere (TOA) reflectance by using two stages. In the first stage, the spectral radiance was calculated from DN value by using following Equation 1:

$R=(D N-1) \times U C C$

Where:

$\mathrm{RR}=$ Radiance $\left(\mathrm{Wm}^{-2} \mathrm{sr}^{-1} \mu \mathrm{m}^{-1}\right)$

$\mathrm{DN}=$ The Digital Number

$\mathrm{UCC}=\mathrm{A}$ Unit Conversion Coefficient

A high gain was used for band 1 and band 2, while a normal gain was needed for band $3 \mathrm{~N}$. The second stage was to use Fast Line-of-sight Atmospheric Analysis of Spectral Hypercubes (FLAASH), an atmospheric correction module implemented in ENVI software (ENVI4.8, 2011) to calibrate the TOA reflectance from radiance.

\section{LULC Classification}

The ASTER image data were classified into five LULC classes: (1) Urban or built-up areas, (2) rangeland, (3) agricultural land, (4) water bodies and (5) barren land, by using Maximum Likelihood (ML) classification method. The ML method is the most popular supervised classification method (Al-Ahmadi and Hames, 2009; Ayanu et al., 2012; Madugundu et al., 2014; Nalina et al., 2014), which is based on the probability that a pixel belongs to a particular class and all classes are assumed to have equal probability and the input bands have normal distributions.

In this study, training data was selected for each five classes according to visual recognition based on reference data as well as ground truth $(n=165)$. These training data were used to guide the classification algorithm to specify spectral values for each class that later were used to assign all pixels in the images to the classes, based on their probabilities.

Stratified random sampling was used to select the reference points for an accuracy assessment. Randomly 1,500 generated points from a classified image in 2002 were compared with a government produced land-use image in 2000. For a classified image in 2009, 250 points were randomly compared with a Google Earth image. In addition, 578 points from Google Earth image were used to compute the accuracy of a classified image in 2011. Google Earth image has been commonly used for accuracy assessment as founded in Carpio and Fath (2011) and Madugundu et al. (2014).

A confusion matrix was constructed to compare, on a class-by-class basis, the relationship between known reference data (a land-use image in 2000 and Google
Earth images in 2009 and 2011) and the corresponding results of classification images (2002, 2009 and 2011). Commission error, omission error, user's accuracy, producer's accuracy and overall accuracy, as well as a Kappa coefficient were calculated to estimate the probability of the correctness of the classification.

\section{LULC Change Detection}

Post-classification comparison method (Mas, 1999; Madugundu et al., 2014) was used to determine the changes of the LULC of the study area. The major advantage of this method is that it provides detailed "from-to" change information and different images from different dates are separately classified, which minimizes the problem of normalizing for atmospheric and sensor differences between those different dates (Singh, 1989). With this method, the areas of change were calculated through a direct comparison of the classified images and the results were presented in the form of a change matrix. In the study, a classification image in 2002 was compared with an image in 2009 to determine the change or lack of change from 2002 to 2009. Similarly, a classification image in 2009 was compared with an image in 2011 to identify the change or lack of change in areas from 2009 to 2011 .

\section{Water Quality and Spatial Distribution}

Archived water quality data from 2000 to 2013 was collected from the Cambodian Ministry of Environment (MoE) to study water quality change. In addition, a field survey was conducted twice in the rainy and dry seasons to study the present conditions and the spatial distribution of water quality in the lake. Water samplings were carried out at 31 and 18 locations, respectively, in October 2-4, 2012 (rainy season) and February1-2, 2013 (dry season) (Fig. 2). The reason for the larger number in the rainy season was the increase in size of the lake, which means that most of the points could be reached, whereas in the dry season many points were on land.

Water quality was checked for chemical, physical and biological parameters, including Total Nitrogen (TN), Total Phosphorous (TP), Total Suspended Solids (TSS), five-day Biochemical Oxygen Demand $\left(\mathrm{BOD}_{5}\right)$, Chemical Oxygen Demand (COD) and chlorophyll-a $(\mathrm{Chl}-a)$. TN and TP are good indicators of the presence of nutrients in the lake, while TSS is the indicator that measures the amount of sediment (Atasoy et al., 2006). $\mathrm{BOD}_{5}$ helps to indicate the pollution load of industrial and domestic effluents in the lake (Scheren et al., 2000). COD is a measure of the susceptibility to oxidation of organic and inorganic materials in water bodies due to effluents from sewage and industrial plants (Chapman, 1992). Also, Chl- $a$ is used to monitor the activity of photosynthesis in phytoplankton that is the food supply for aquatic creatures in the lake and also to offer information about the tropic status of the lake. 

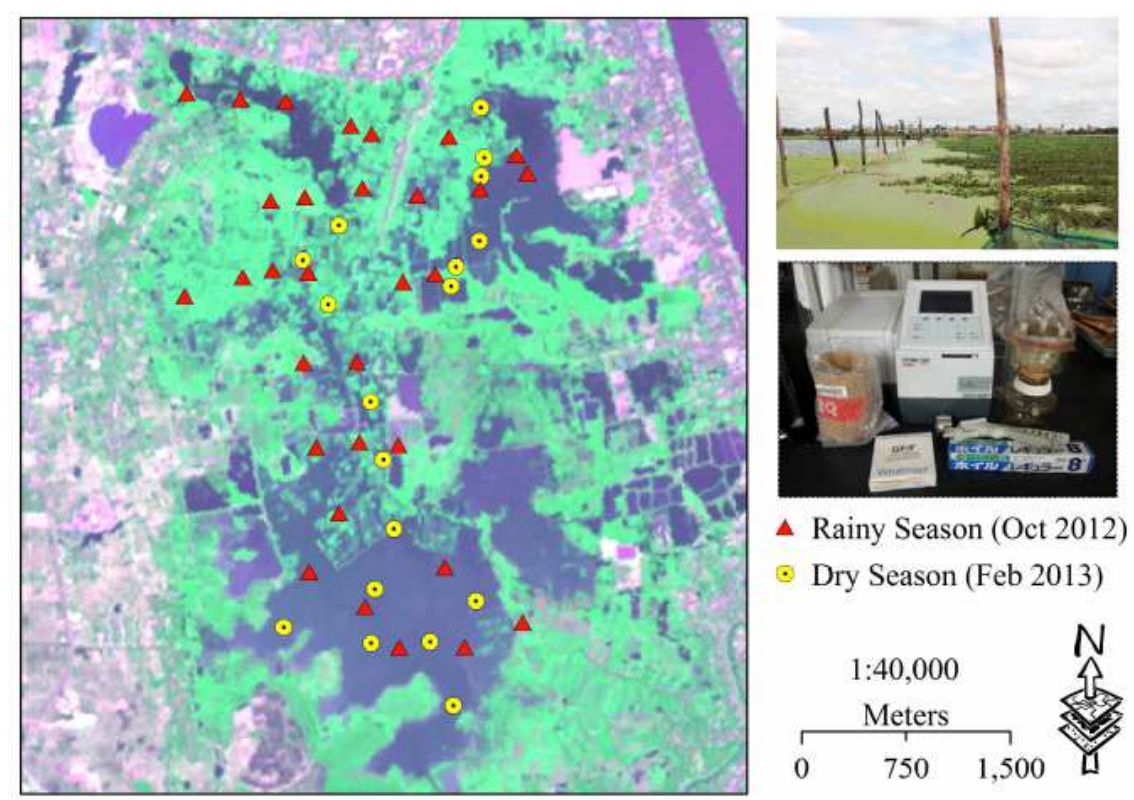

Fig. 2. Sampling points in rainy and dry seasons in Cheung Ek Lake (left) and tools and condition of the lake (right)

To map the spatial distribution of TN, TP, TSS, $\mathrm{BOD}_{5}$, COD and Chl- $a$, geo-statistical analyses were made using R software version 3.0.0 (RCT, 2013) with several packages including "gstat", "automap", "sp", "lattice", "rgdal", "spatialkernel" and "colorRamps". The spatial dependence of the parameters was determined from a semivariace $\gamma(h)$ value by fitting the linear, spherical, exponential and gaussian, Matern and M. Stein's models, to determine the most suitable one. Then, ordinary kriging was used to estimate the spatial distribution of water parameters within the target lake. The semivariance value was defined as below equation (Crist, 1998; Kawamura et al., 2009; Lim et al., 2012; Webster, 1985):

$\gamma(h)=\frac{1}{2 N(h)} \sum_{i=1}^{N}\left[z\left(x_{i}\right)-z\left(x_{i+h}\right)\right]^{2}$

Where:

$h=$ The lag distance between $N$ sample pairs

$x_{i}=$ A location

$z\left(x_{i}\right)=$ The measured value at location $x_{i}$

$z\left(x_{i+h}\right)=$ The sample value at point $x_{i+h}$

$N(h)=$ A function of the lag distance

\section{Results}

\section{LULC Classification}

In the LULC classification using ASTER imageries, ML gave moderate level of accuracy. The overall accuracy of image classification in 2002, 2009 and 2011 were 58,59 and $64 \%$ with Kappa coefficient of 0.47, 0.48 and 0.48 , respectively.
Through the confusion matrixes of Table 1 to 3 , agricultural land, barren land and urban or built-up area had very low user's and producer's accuracy among all classes. For image classification in 2002, agricultural land had only $35.60 \%$ of user's accuracy and barren land had 39\% of producer's accuracy. For image classificaion in 2009, agricultural land had user's accuracy of $37.18 \%$, while barren land had 42.86 and $37.5 \%$ of user's and producer's accuracy, respectively and for image classificaion in 2011, barren land and urban or built-up area had the same percentage (50\%) for user's accuracy and had respective $22.81 \%$ and $46.51 \%$ for producer's accuracy.

The distribution of LULC in the study area was quite similar in all three dates (Fig. 3). Most of the area to the north of the Cheung Ek Lake (the upper part of the study area) was occupied by urban or built-up areas because it was the core city's zone. Also, there were some rangelands and agricultural land to the south of the city that were the wetlands of the Tumpun and Trabek Lakes (north of Cheung Ek Lake). To the west of the lake, the main type of LULC was agricultural land and some spots of barren lands. To the east, the main type was urban or built-up areas. In between the lake and the area to the east and the west, the land was dominated by rangeland. To the south of the lake, there was a mixture of rangeland, agricultural land and small water bodies, as well as urban or built-up areas.

\section{LULC Change Detection}

The post-classification comparison method revealed that changes occurred to all LULC classes in the study area between 2002 and 2011. Among those, 
rangeland, agricultural land and urban or built-up area had significant change.

From 2002 to 2009 (Table 4), rangeland decreased by $1.35 \mathrm{~km}^{2}(22.86 \%)$, while agricultural land and urban or built-up areas increased by $8.83 \mathrm{~km}^{2}(24.19 \%)$ and 1.25 $\mathrm{km}^{2}(5.32 \%)$, respectively. Conversely, from 2009 to 2011 (Table 5), rangeland increased by $2.13 \mathrm{~km}^{2}$ $(14.49 \%)$ and agricultural land decreased by $7.96 \mathrm{~km}^{2}$ $(17.56 \%)$. However, the urban or build-up area still increased by $2.55 \mathrm{~km}^{2}(10.37 \%)$. In general, from 2002 to 2011 rangeland decreased by $22.9 \%$ and agricultural land and urban or build-up area increased by approximately 2.38 and $16.19 \%$, respectively.

\section{Water Quality Status and Distribution in Cheung Ek Lake}

The water of the lake in both dry and rainy seasons was badly polluted, as indicated by the monitored parameters (Table 6). The mean values of most parameters were much higher than the standard value of water quality for the lake set in the sub-decree on water pollution control by the Cambodia Ministry of Environment even the water quality status in rainy season was much better than in dry season. However, the concentrations of the parameters shown on spatial distribution maps (Figs. 4 and 5) had wide variation for different points in the lake.

In dry season (Fig. 4), the concentration of $\mathrm{TN}$ and TP were very high in the upper part of the lake, where wastewater from the city is discharged into the lake through the Trabek, Tumpun and Iron Bridge pumping stations. However, their concentration lowered as the water flows to the south of the lake. COD was high at the inlet point and in a lower part of the lake. In contrast, Chl- $a$ and TSS were highly concentrated in the middle part of the lake compared to the upper part.

Table 1. Confusion matrix of classification image in 2002

\begin{tabular}{|c|c|c|c|c|c|c|c|}
\hline \multirow[b]{2}{*}{ Classification image 2002} & \multicolumn{5}{|c|}{ Land use 2000} & \multirow{2}{*}{$\begin{array}{l}\text { Row } \\
\text { total }\end{array}$} & \multirow{2}{*}{$\begin{array}{l}\text { User's } \\
\text { accuracy }\end{array}$} \\
\hline & RL & AL & WB & BL & UBA & & \\
\hline Rangeland (RL) & 189.00 & 50.00 & 59.00 & 14.00 & 10.00 & 322 & 58.70 \\
\hline Agricultural Land (AL) & 56.00 & 162.00 & 24.00 & 121.00 & 92.00 & 455 & 35.60 \\
\hline Water Bodies (WB) & 41.00 & 19.00 & 207.00 & 10.00 & 1.00 & 278 & 74.46 \\
\hline Barren Land (BL) & 3.00 & 29.00 & 3.00 & 117.00 & 6.00 & 158 & 74.05 \\
\hline Urban or Built-up Areas (UBA) & 11.00 & 40.00 & 7.00 & 38.00 & 191.00 & 287 & 66.55 \\
\hline Column total & 300.00 & 300.00 & 300.00 & 300.00 & 300.00 & 1500 & \\
\hline Producer's accuracy (\%) & 63.00 & 54.00 & 69.00 & 39.00 & 63.67 & $\begin{array}{l}\text { Overe } \\
\text { Kapp }\end{array}$ & $\begin{array}{l}c y=58 \% \\
\text { ent }=0.47\end{array}$ \\
\hline
\end{tabular}

Table 2. Confusion matrix of classification image in 2009

\begin{tabular}{|c|c|c|c|c|c|c|c|}
\hline \multirow[b]{2}{*}{ Classification image 2009} & \multicolumn{5}{|c|}{ Google earth 2009} & \multirow{2}{*}{$\begin{array}{l}\text { Row } \\
\text { total }\end{array}$} & \multirow{2}{*}{$\begin{array}{l}\text { User's } \\
\text { accuracy }\end{array}$} \\
\hline & RL & $\mathrm{AL}$ & WB & BL & UBA & & \\
\hline Rangeland (RL) & 26.00 & 7.00 & 6.00 & 0.0 & 2.00 & 41 & 63.41 \\
\hline Agricultural Land (AL) & 17.00 & 29.00 & 6.00 & 14.0 & 12.00 & 78 & 37.18 \\
\hline Water Bodies (WB) & 4.00 & 0.00 & 42.00 & 1.0 & 2.00 & 49 & 85.71 \\
\hline Barren Land (BL) & 0.00 & 5.00 & 3.00 & 12.0 & 8.00 & 28 & 42.86 \\
\hline Urban or Built-up Areas (UBA) & 0.00 & 7.00 & 4.00 & 5.0 & 38.00 & 54 & 70.37 \\
\hline Column total & 47.00 & 48.00 & 61.00 & 32.0 & 62.00 & 250 & \\
\hline Producer's accuracy (\%) & 55.32 & 60.42 & 68.85 & 37.5 & 61.29 & $\begin{array}{l}\text { Overa } \\
\text { Kapp }\end{array}$ & $\begin{array}{l}\text { cy }=59 \% \\
\text { ent }=0.48\end{array}$ \\
\hline
\end{tabular}

Table 3. Confusion matrix of classification image in 2011

\begin{tabular}{|c|c|c|c|c|c|c|c|}
\hline \multirow[b]{2}{*}{ Classification image 2011} & \multicolumn{5}{|c|}{ Google earth 2011} & \multirow{2}{*}{$\begin{array}{l}\text { Row } \\
\text { total }\end{array}$} & \multirow{2}{*}{$\begin{array}{l}\text { User's } \\
\text { accuracy }\end{array}$} \\
\hline & RL & $\mathrm{AL}$ & WB & BL & UBA & & \\
\hline $\begin{array}{l}\text { Rangeland (RL) } \\
\text { (RL) }\end{array}$ & 55.0 & 34.00 & 10.00 & 4.00 & 3.00 & 106 & 51.89 \\
\hline Agricultural Land (AL) & 32.0 & 205.00 & 7.00 & 25.00 & 26.00 & 295 & 69.49 \\
\hline Water Bodies (WB) & 15.0 & 5.00 & 65.00 & 4.00 & 2.00 & 910 & 71.43 \\
\hline Barren Land (BL) & 2.0 & 5.00 & 2.00 & 13.00 & 4.00 & 260 & 50.00 \\
\hline Urban or Built-up Areas (UBA) & 3.0 & 14.00 & 2.00 & 11.00 & 30.00 & 600 & 50.00 \\
\hline Column total & 107.0 & 263.00 & 86.00 & 57.00 & 65.00 & 578 & \\
\hline Producer's accuracy (\%) & 51.4 & 77.95 & 75.58 & 22.81 & 46.15 & $\begin{array}{l}\text { Over } \\
\text { Kapp }\end{array}$ & $\begin{array}{l}a c y=64 \% \\
\text { cient }=0.48\end{array}$ \\
\hline
\end{tabular}


Nara Im et al. / American Journal of Environmental Sciences 2015, 11 (1): 1.12 DOI: 10.3844/ajessp.2015.1.12

Table 4. LULC change by class from 2002 to 2009

\begin{tabular}{|c|c|c|c|c|c|c|}
\hline \multirow[b]{2}{*}{ LULC categories } & \multicolumn{6}{|c|}{$2002\left(\mathrm{~km}^{2}\right)$} \\
\hline & RL & $\mathrm{AL}$ & WB & $\mathrm{BL}$ & UBA & Class total \\
\hline \multicolumn{7}{|l|}{$2009\left(\mathrm{~km}^{2}\right)$} \\
\hline Rangeland (RL) & 9.05 & 2.90 & 2.16 & 0.10 & 0.48 & 14.70 \\
\hline Agricultural Land (AL) & 8.19 & 22.56 & 2.40 & 3.30 & 8.91 & 45.36 \\
\hline Water Bodies (WB) & 2.11 & 0.65 & 6.55 & 0.17 & 0.66 & 10.15 \\
\hline Barren Land (BL) & 0.42 & 2.25 & 0.23 & 0.83 & 0.83 & 4.56 \\
\hline Urban or Built-up Areas (UBA) & 1.60 & 8.16 & 0.86 & 1.51 & 12.58 & 24.71 \\
\hline Class total & 21.38 & 36.53 & 12.20 & 5.91 & 23.46 & 99.48 \\
\hline Net change & -6.68 & 8.83 & -2.05 & -1.35 & 1.25 & \\
\hline Change $(\%)$ & -31.24 & 24.19 & -16.82 & -22.86 & 5.32 & \\
\hline
\end{tabular}

Table 5. LULC change by class from 2009 to 2011

\begin{tabular}{|c|c|c|c|c|c|c|}
\hline \multirow[b]{2}{*}{ LULC categories } & \multicolumn{5}{|c|}{$2009\left(\mathrm{~km}^{2}\right)$} & \multirow[b]{2}{*}{ Class total } \\
\hline & RL & $\mathrm{AL}$ & WB & $\mathrm{BL}$ & UBA & \\
\hline \multicolumn{7}{|l|}{$2011\left(\mathrm{~km}^{2}\right)$} \\
\hline Rangeland (RL) & 8.39 & 7.09 & 0.59 & 0.12 & 0.64 & 16.83 \\
\hline Agricultural Land (AL) & 2.99 & 24.92 & 0.84 & 1.54 & 7.11 & 37.40 \\
\hline Water Bodies (WB) & 2.32 & 1.15 & 7.93 & 0.13 & 0.82 & 12.35 \\
\hline Barren Land (BL) & 0.29 & 1.91 & 0.19 & 1.32 & 1.93 & 5.64 \\
\hline Urban or Built-up Areas (UBA) & 0.70 & 10.29 & 0.61 & 1.46 & 14.21 & 27.26 \\
\hline Class total & 14.70 & 45.36 & 10.15 & 4.56 & 24.71 & 99.48 \\
\hline Net change & 2.13 & -7.96 & 2.20 & 1.08 & 2.55 & \\
\hline Change $(\%)$ & 14.49 & -17.56 & 21.67 & 23.53 & 10.37 & \\
\hline
\end{tabular}

Table 6. Water quality of Cheung Ek Lake and the standard values

\begin{tabular}{lllll}
\hline Para-meters & Unit & Dry season & Rainy season & Standard value \\
\hline pH & $8.32 \pm 0.97$ & $8.52 \pm 1$ & 0.00 & $6.5-8.5$ \\
COD & $\mathrm{mg} / \mathrm{L}$ & $67.01 \pm 38.89$ & $27.53 \pm 15.31$ & $1-8$ \\
TSS & $\mathrm{mg} / \mathrm{L}$ & $22 \pm 15.33$ & $21.52 \pm 8.50$ & $1-15$ \\
TN & $\mathrm{mg} / \mathrm{L}$ & $11.64 \pm 3.03$ & $5.58 \pm 1.92$ & $0.1-0.6$ \\
TP & $\mathrm{mg} / \mathrm{L}$ & $1.47 \pm 0.35$ & $2.43 \pm 0.92$ & $0.005-0.05$ \\
$\mathrm{Chl}-\alpha$ & $\mathrm{mg} / \mathrm{m}^{3}$ & $199.67 \pm 179.8$ & $100 \pm 45.79$ & NA \\
$\mathrm{BOD}_{5}$ & $\mathrm{mg} / \mathrm{L}$ & $87.24 \pm 78.22$ & $77.77 \pm 78.12$ & NA \\
\hline
\end{tabular}

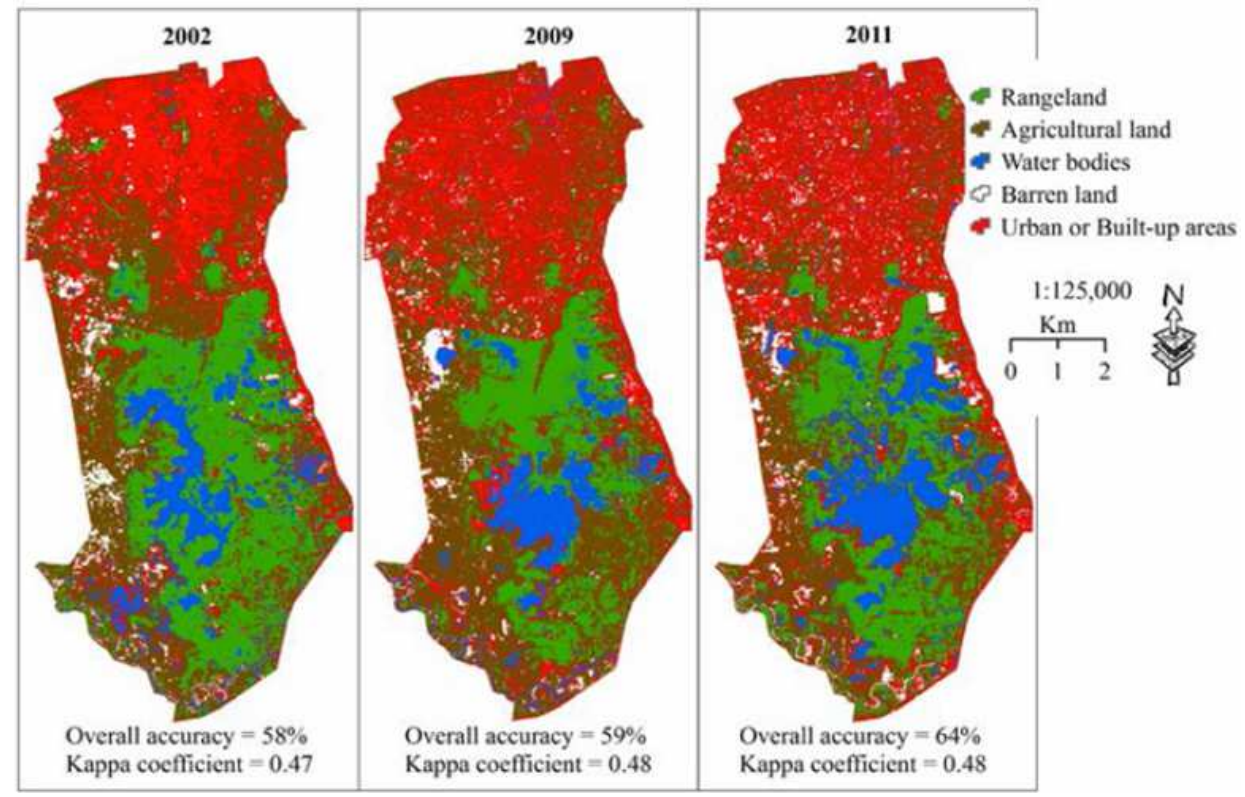

Fig. 3. Land Use and Land Cover (LULC) maps in 2002, 2009 and 2011 
$\mathrm{TN}(\mathrm{mg} / \mathrm{L})$

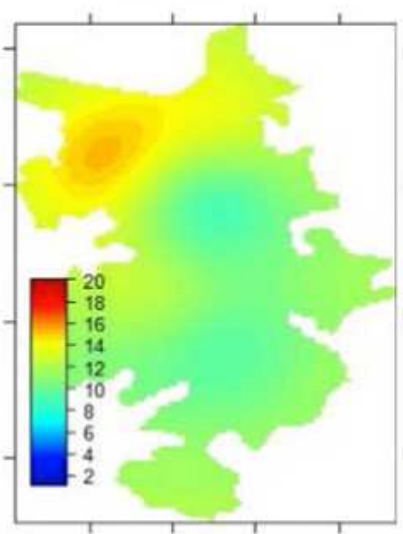

TSS $(\mathrm{mg} / \mathrm{L})$
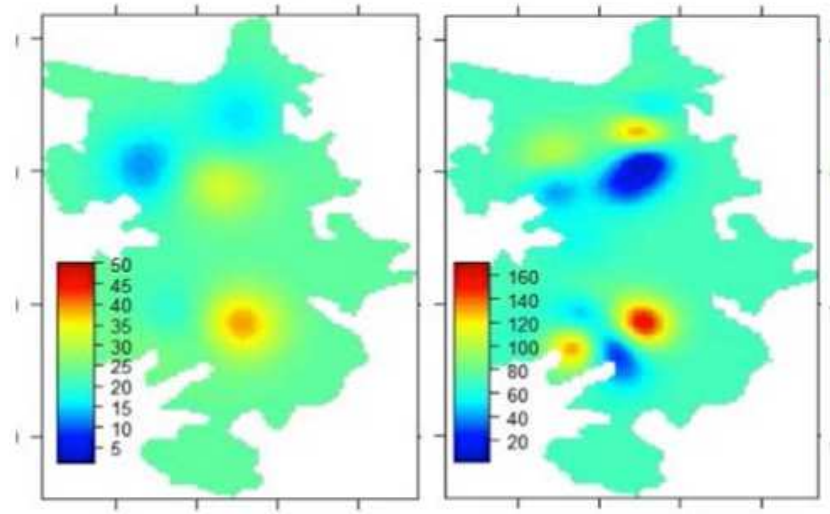

Chl_a $\left(\mathrm{mg} / \mathrm{m}^{3}\right)$

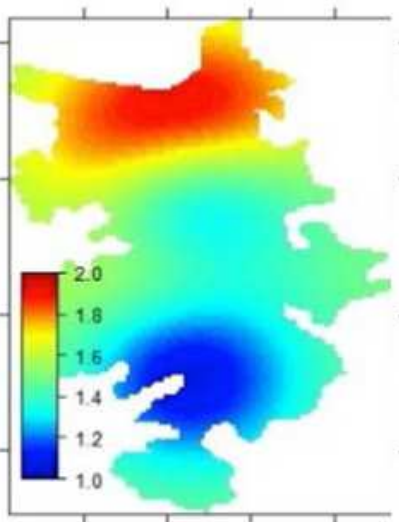

$\mathrm{COD}(\mathrm{mg} / \mathrm{L})$
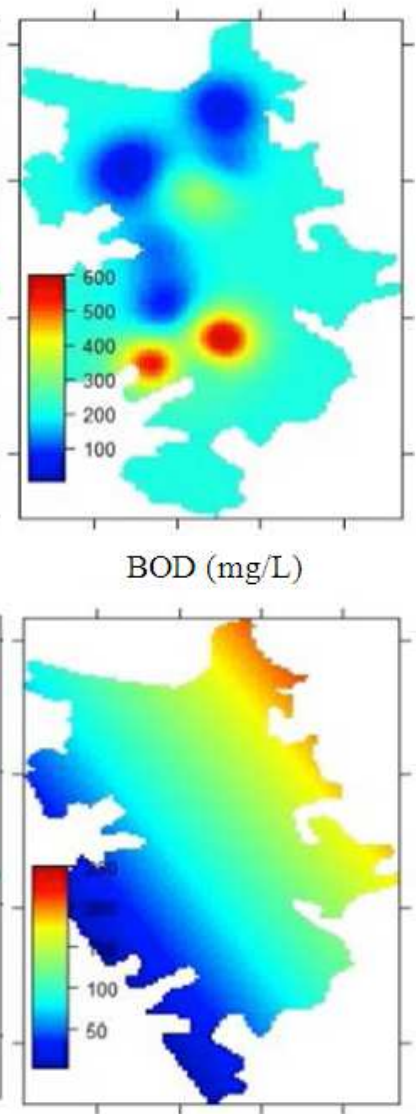

Fig. 4. Spatial distribution of water quality parameters in the dry season, February 2013
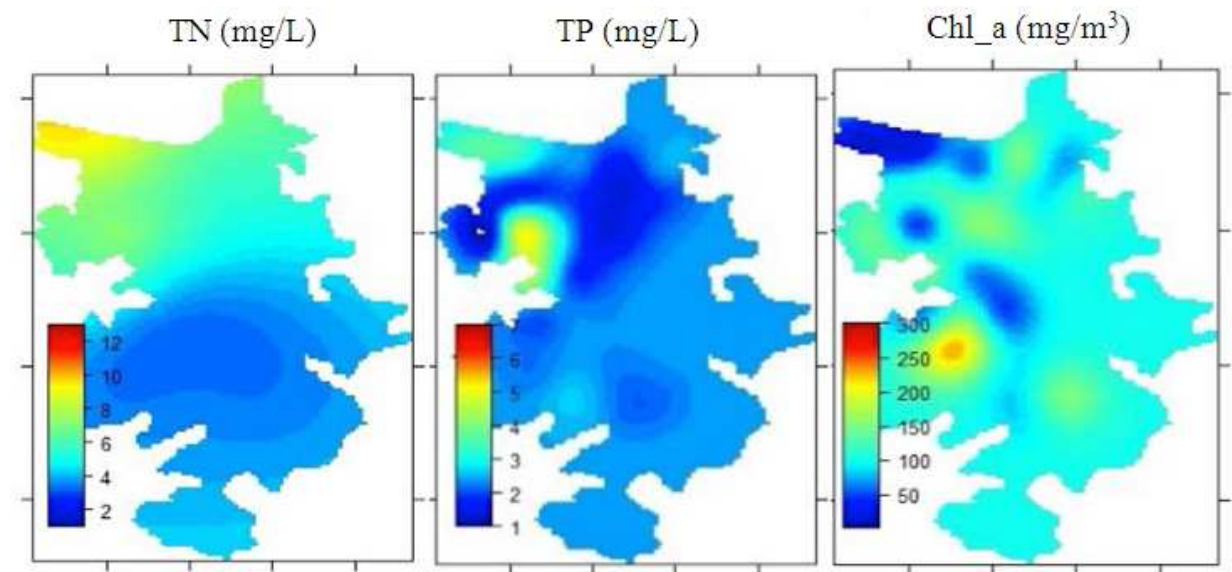

Fig. 5. Spatial distribution of water quality parameters in the rainy season, October 2012

Similarly, the spatial distributions of the parameters in the rainy season (Fig. 5) were not so different from those in the dry season, especially for $\mathrm{TN}$ and TP. COD and $\mathrm{BOD}_{5}$ also showed a high concentration at the upper part of the lake and low concentration at the southern part of the lake. Chl- $a$, on the other hand, was high to the west side of the lake and near the upper part of the lake, but was very low near the Iron Bridge (inlet point). Unfortunately, the data were not able to explain very well the distribution of $\mathrm{BOD}_{5}$ for dry season and TSS, COD and $\mathrm{BOD}_{5}$ for rainy season. 
$\mathrm{BOD}(\mathrm{mg} / \mathrm{L})$

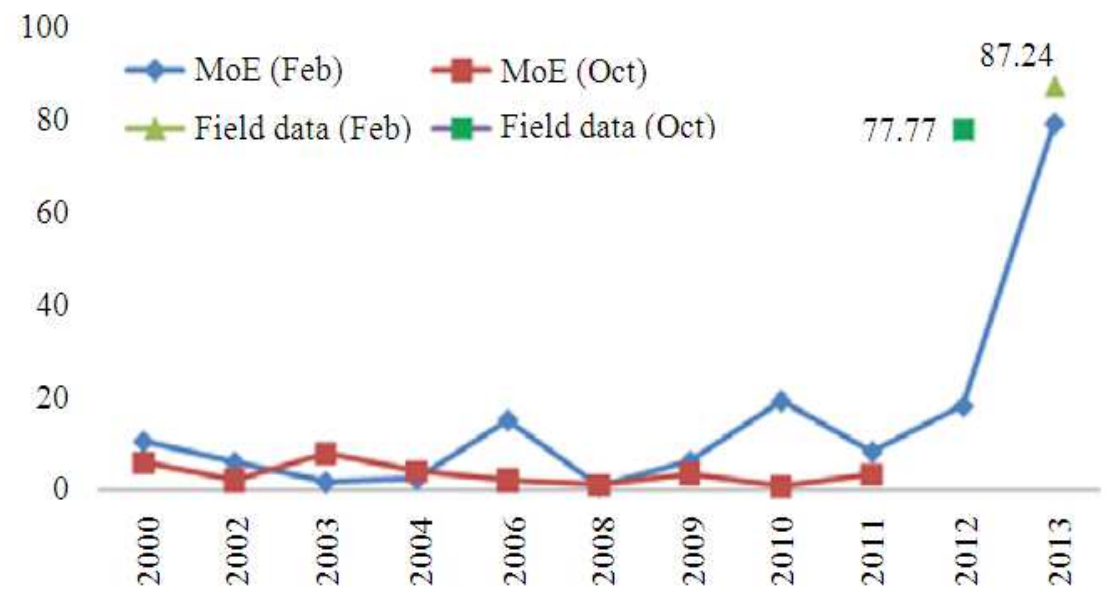

Fig. 6. Trend of BOD recorded by MoE and the field data

$$
\mathrm{COD}(\mathrm{mg} / \mathrm{L})
$$

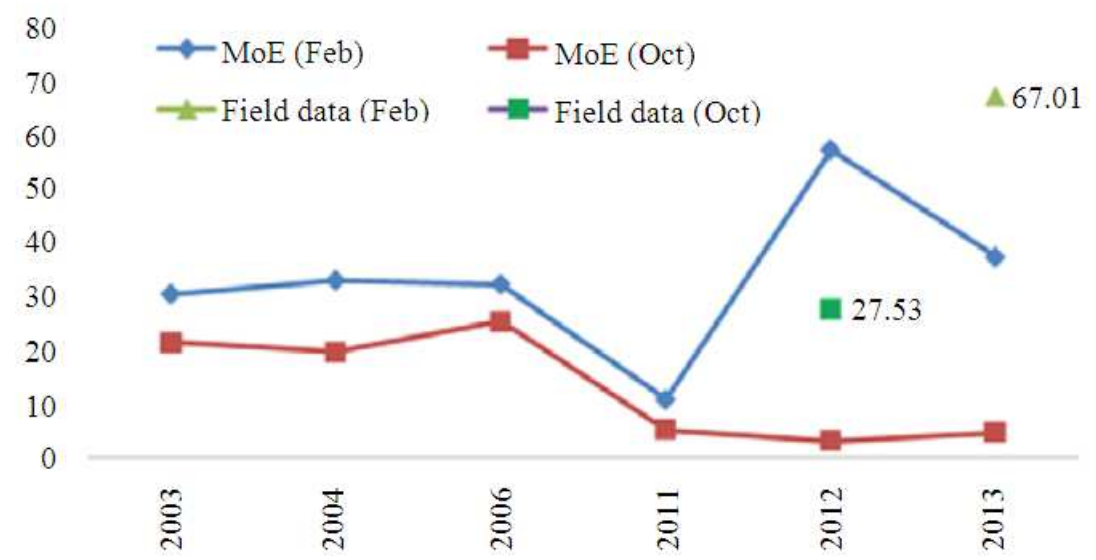

Fig. 7. Trend of COD recorded by MoE and the field data

$\mathrm{TP}(\mathrm{mg} / \mathrm{L})$

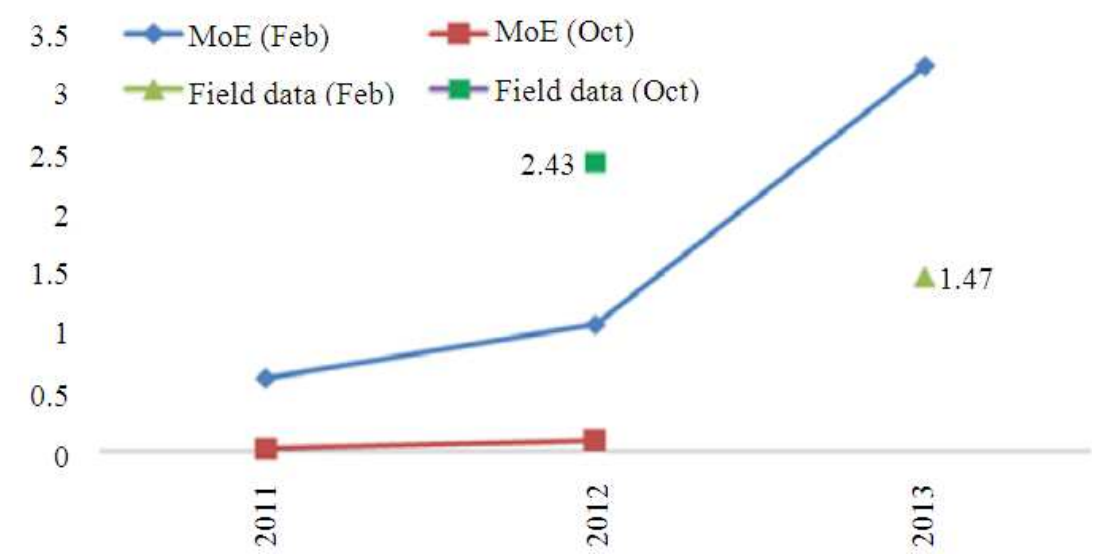

Fig. 8. Trend of TP recorded by MoE and the field data 
$\mathrm{TN}(\mathrm{mg} / \mathrm{L})$

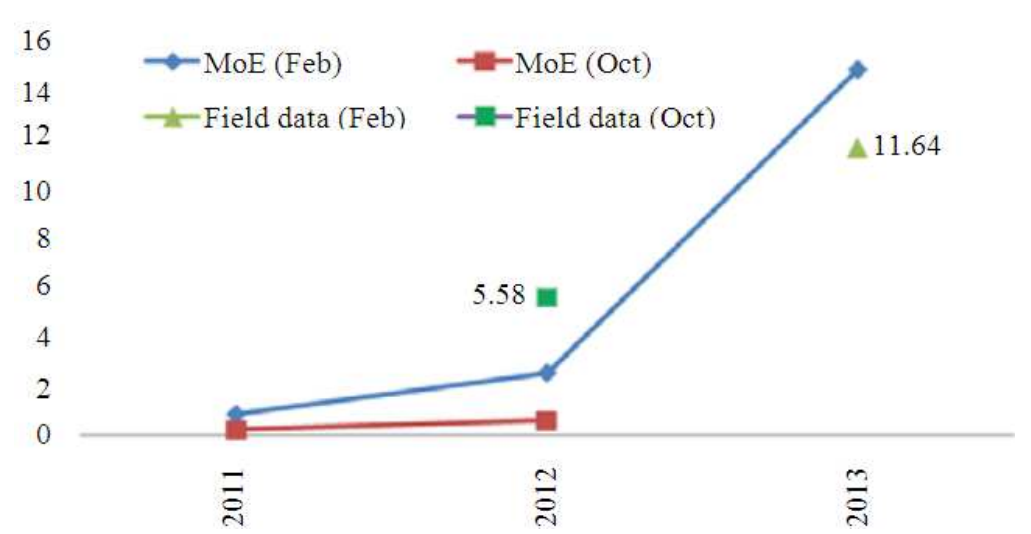

Fig. 9. Trend of TN recorded by $\mathrm{MoE}$ and the field data

Concerning the trend of changes, MoE data revealed that water quality in the lake gradually became polluted, especially in the dry season. The data also showed that the concentration of $\mathrm{BOD}_{5}$ moderately increased from 2000 to 2013, while COD, TN and TP dramatically rose from 2010 to 2013. Figure 6 to 9 showed the trend of water quality status changes for BOD, COD, TN and TP compared with the filed data of this study.

\section{Discussion}

\section{LULC Classification}

It was clear that the result of the classification was owing to nature of LULC in the study area and the low classificaion accuracy of agricultural land, barren land and urban or built-up area was because of their spectral value could not be differentiated from one another and other classes.

Uncultivated agricultural land in the dry season and the agricultural land in the preparation stage (lands were left uncovered as soil- or rock-like land) were wrongly identified with those barren lands that were in a transitional stage (to be developed) and covered by croplike plants. Also, Barren land was usually classified into those very turbid and shallow water bodies that were caused by sediments because the spectral values of these groups were near to identical.

The dark surface of urban or built-up areas, resulting from the shadows of tall buildings or from forest canopy, were classified into water bodies owing to their similar spectral characteristics and urban or built-up areas, which are usually a mixture of vegetation and settlement, was also interpolated with the agricultural land. Similar case similar to $\mathrm{Lu}$ and Weng (2006) who also found that in low resolution image the water bodies or shadow and dark impervious surface [urban or built-up area] usually have undifferentiated spectral values and error in an estimation of impervious surface happened in the lessdeveloped area where there were mixture of impervious surfaces, vegetation and soil. Ikiel et al. (2013) who used Landsat TM to study land cover change also support that the classification accuracy of the urban or built-up area was very low as a result of heterogeneous character of this area.

\section{LULC Change Detection}

The study depicted the anthropogenic effects on LULC in the area, especially the decrease of rangeland and the rapid growth of urban or built-up areas.

The first interesting change is the decrease of rangeland from $21.38 \mathrm{~km}^{2}$ in 2002 to less than $16 \mathrm{~km}^{2}$ in 2011. Conversion of rangeland to agricultural land and land filling in tumpun and trabek lakes (north of Cheung Ek Lake) for settlement development were the reasons for the decrease in rangeland.

Agricultural land got similar effects. Agricultural land had increased from $36.53 \mathrm{~km}^{2}$ in 2002 to $45.36 \mathrm{~km}^{2}$ in 2009, when most of the rangeland was cleared for cultivation. However, from 2009 to 2011 , the size of the agricultural land started decreasing to $37.40 \mathrm{~km}^{2}$ in 2011 as a result of urban sprawl in the last several years when land prices have increased, causing agricultural land to be developed into built-up areas. In addition, some agricultural lands were not cultivated anymore that allowed shrubbery to regenerate, especially those agricultural lands nearby the lake.

The growth of urban or built-up areas from 23.46 $\mathrm{km}^{2}$ in 2002 to $27.26 \mathrm{~km}^{2}$ in 2011 was the most interesting change. There were some factors behind the growth of urban or built-up areas and barren land. Primarily, it was population that growth from around 1.38 million in 2004 to nearly 1.6 million in 2010 
(Doyle, 2012). This was due to people moving from the provinces to the city to find jobs and a better education. Another reason was the increasing price of land resulting in the trend to drain and fill the wetlands and in the developing of agricultural land for urban settlement (Yim et al., 2008). This growth had resulted in transformation of those former agricultural lands and rangelands ringing tumpun and trabek lakes and also of those agricultural land and rangeland to the west of the city (north-west of the lake) into settlements and impervious areas.

\section{Water Quality Status}

There is no difference from previous studies in that the lake's water quality was very poor in comparison with the standard. The main reason was the increase in the direct discharge of wastewater from the city into the lake without proper treatment. The increase in wastewater seem clear when comparing the per capita water consumption shown in (Biswas and Tortajada, 2010) with the amount of wastewater in 2011 and it could be assumed to be a great deal higher than that in 2002, as found by Muong (2004). This increase in the amount of wastewater could be explained by the increase in residents and industries in the area.

Also, the better status of water quality in rainy season compared to dry season could be due to large amounts of water flowing into the lake from the Bassac River and storm-water from its sub-catchment area in the city that diluted the water in the lake resulted in a lower concentration of water quality parameters. The result agreed with previous study by Khov et al. (2005) that the water quality of the lake was poor in the dry season, starting from January and became more severe in March owing to the receding water level, but then got better in the rainy season when the water level was high.

Concerning the distribution of parameters monitored in the dry season (Fig. 4), especially TN and $\mathrm{TP}$, the most plausible explanation was the efficiency of the lake in purifying wastewater. The abundance of aquatic plants, such as water spinach and water mimosa grown by farmers and water hyacinth growing naturally, was likely to be the most important factor involved in the high reduction of concentrations of TN and TP. This could be further supported by the findings of Sovann et al. (2011), who found that 79 of $\mathrm{TN}$ and $59 \%$ of TP were efficiently removed by the lake. In addition, COD had high concentration near the inlet point because the wastewater from the city originated from both households and industries, while its low abundance at the lower part of the lake during the dry season because that part is the deepest area in the lake, where water flows into, circulates and accumulates before going to the Mekong River through the Steung Chrov stream. In the case of TSS, its concentration was high throughout the lake in the dry season. However, it was found to be significantly higher at the same sites as COD, especially in the lower part of the lake. The activities of farmers' boats, navigating and fishing, could be a cause of this high concentration.

The distribution of water quality parameters in the rainy season (Fig. 5), especially the high concentrations at the inlet point of TN, TP, COD and BOD5, could be explained by two possible reasons. The first reason was the high concentration of these parameters in wastewater from the city. The second reason was the inverse flow direction of water coming in from the Mekong River at the southeast part of the lake. This water moving in the opposite direction (Sovann et al., 2011) really pushed the wastewater back to the upper part of the lake, which then made the concentration of the parameters high near the shore at the inlet points.

\section{Effects of LULC on Water Quality}

It was clear that changes happened to all types of LULC, especially the increase of urban or built-up areas as a result of the conversion of agricultural land as well as rangeland and especially the decrease of rangeland happening at the lake and at the Tumpun and Trabek Lakes, in the study area from 2002 to 2009 and from 2009 to 2011 . At the meantime, the wate quality data of the MoE also showed that water quality of the lake has been changing to a more polluted condition.

By observing these parallel trends of LULC change and water quality change, LULC changes appear to have negative effects on the water quality of the lake because the LULC changes could possibly result in reducing the lake's capacity in purifying wastewater.

This assumption was supported by a comparison of the efficiency of the lake in TP removal in the dry season in 2011 founded by Sovann et al. (2011) with that found by Irvine (2010) in 2007-2008. It clearly showed that the efficiency of removal decreased from 71 to $31 \%$ from $2007-2008$ to 2011 .

However, this assumption was based only on one variable (TP) of water quality parameters that further study to compare more variables should be made.

\section{Conclusion}

Cheung Ek Lake is an important wetland, playing a role as an efficient natural treatment plant for almost all of the wastewater from Phnom Penh, the capital city of Cambodia. As a result of urban sprawl, along with unmanageable urban development, some parts of the lake and its catchment area have been undergoing change, especially during the period from 2002 to 2011, as found in this study. Rangeland has been converted to agricultural land or urban or built-up 
areas, agricultural land has been changed into urban or built-up areas, water bodies have been filled for development and so on. Meanwhile, the water quality of the lake has also been changing to a more polluted condition. By observing these trends, it can be inferred that LULC changes appear to have negative effects on the water quality of the lake.

\section{Acknowledgement}

We are grateful to Mr. Him Chandath and all the staffs of the Environmental Quality Research and Laboratory Office of the Ministry of Environment, Cambodia, for their support in water sampling and analysis. This study was supported by the Japanese Grant Aid for Human Resource Development Scholarship (JDS), Japan International Cooperation Agency (JICA) and the Global Environmental Leaders Education Program for Designing a Low-Carbon World (GELs) of Hiroshima University, Japan. ASTER data was provided ARO on ASTER data use and right to data belongs to Ministry of Economy, Trade and Industry, Japan.

\section{Author's Contributions}

Im Nara and Kensuke Kawamura designed and organized this study. Im Nara collected the field data, and performed all the statistical and image analysis, with the co-authors (Kensuke Kawamura, Endan Suwandana and Yuji Sakuno) providing mentorship throughout the study. Im Nara and Kensuke Kawamura jointly wrote the manuscript. All authors have read and approved this manuscript.

\section{Ethics}

The authors declare no conflicts of interest.

\section{References}

Al-Ahmadi, F.S. and A.S. Hames, 2009. Comparison of four classification methods to extract land use and land cover from raw satellite images for some remote arid areas, Kingdom of Saudi Arabia. J. King Abdulaziz University-Earth Sci., 20: 167-191.

Atasoy, M., R.B. Palmquist and D.J. Phaneuf, 2006. Estimating the effects of urban residential development on water quality using microdata. J. Environ. Manage., 79: 399-408. DOI: $10.1016 /$ j.jenvman.2005.07.012

Ayanu, Y.Z., C. Conrad, T. Nauss, M. Wegmann and T. Koellner, 2012. Quantifying and mapping ecosystem services supplies and demands: A review of remote sensing applications. Environ. Sci. Tech., 46: 8529-8541. DOI: 10.1021/es300157u
Biswas, A.K. and C. Tortajada, 2010. Water supply of Phnom Penh: An example of good governance. Int. J. Water Resour. Dev., 26: 157-172. DOI: $10.1080 / 07900621003768859$

Carpio, O.V. and B.D. Fath, 2011. Assessing the environmental impacts of urban growth using land use/land cover, water quality and health indicators: A case study of Arequipa, Peru. Am. J. Environ. Sci., 7: 90-101. DOI: 10.3844/ajessp.2011.90.101

Chapman, D.V., 1992. Water quality Assessments: A Guide to the Use of Biota, Sediments and Water in Environmental Monitoring. 2nd Edn., CRC Press, London, New York, Chapman and Hall, ISBN-10: 0203476719, pp: 648.

Chea, E., V. Dany and K. Irvine, 2010. Level of Cr, $\mathrm{Cu}$ and $\mathrm{Zn}$ in food stuffs from a wastewater treatment wetland, Phnom Penh: A preliminary assessment of health risks. Asian J. Water Environ. Pollut., 7: 23-30.

Crist, T.O., 1998. The spatial distribution of termites in shortgrass steppe: A geostatistical approach. Oecologia, 114: 410-416. DOI: $10.1007 / \mathrm{s} 004420050464$

Doyle, S.E., 2012. City of water: Architecture, urbanism and the floods of Phnom Penh. J. Environ. Design Plann., 8: 1-1.

ENVI4.8, 2011. FLAASH module user's guide (Version 4.4). Exelis Visual Information Solutions, Boulder, CO, USA.

Forney, W., L. Richards, K.D. Adams, T.B. Minor and C.G. Raumann et al., 2001. Land use change and effects on water quality and ecosystem health in the Lake Tahoe Basin, Nevada and California.

Ikiel, C., B. Ustaoglu, A.A. Dutucu and D.E. Kilic, 2013. Remote sensing and GIS-based integrated analysis of land cover change in Duzce plain and its surroundings (north western Turkey). Environ. Monit. Assess., 185: 1699-1709. DOI: $10.1007 / \mathrm{s} 10661-012-2661-6$

Irvine, K. and T. Koottatep, 2010. Natural wetlands treatment of sewage discharges from Phnom Penh, Cambodia: Successes and future challenges. Asian J. Water Environ. Pollut., 7: 1-2.

Irvine, K., 2010. Efficiency of Phnom Penh's natural wetlands in treating wastewater discharges. Asian J. Water Environ. Pollut., 7: 39-48.

Kawamura, K., K. Betteridge, I.D. Sanches, M.P. Tuohy and Y. Inoue et al., 2009. Field radiometer with canopy pasture probe as a potential tool to estimate and map pasture biomass and mineral components: A case study in the Lake Taupo catchment, New Zealand. New Zealand J. Agric. Res., 52: 417-434. DOI: $10.1080 / 00288230909510524$ 
Khov, K., S. Daream and C. Borin, 2005. Periurban aquatic food production systems in Phnom Penh. UA-Magazine, 2.

Khov, K., W. Leschen and D. Little, 2007. Food, incomes and urban waste water treatment in Phnom Penh, Cambodia. Aquaculture News, 33: 3-3.

Lim, J., K. Kawamura, H.J. Lee, T. Tachikawa, R. Yoshitoshi and N. Watanabe, 2011. A hand-held crop measuring device for assessing spatial variability of herbage biomass and LAI in an Italian ryegrass field. Proceedings of the $32 \mathrm{nd}$ Asian Conference on Remote Sensing, Oct 3-7.

Lu, D. and Q. Weng, 2006. Use of impervious surface in urban land-use classification. Remote Sens. Environ., 102: 146-160. DOI: $10.1016 /$ j.rse.2006.02.010

Madugundu, R., K.A. Al-Gaadi, V.C. Patil and E. Tola, 2014. Detection of land use and land cover changes in Dirab region of Saudi Arabia using remotely sensed imageries. Am. J. Environ. Sci., 10: 8-18. DOI: 10.3844/ajessp.2014.8.18

Mas, J.F., 1999. Monitoring land-cover changes: A comparison of change detection techniques. Int. J. Remote Sens., 20: 139-152. DOI: $10.1080 / 014311699213659$

Muong, S., 2004. Avoiding adverse health impacts from contaminated vegetables: Options for three wetlands in Phnom Penh, Cambodia.

Nalina, P., T. Meenambal and R. Sathyanarayan Sridhar, 2014. Land use land cover dynamics of Nilgiris district, India inferred from satellite imageries. Am. J. Applied Sci., 11: 455-461.

DOI: 10.3844/ajassp.2014.455.461

NIS, 1998-2008. General population census.

PPCH, 2010. Facts phnom penh city. Phnom Penh City Hall.

RCT, 2013. R: A language and environment for statistical computing. $\mathrm{R}$ foundation for statistical computing, Vienna, Austria.
Scheren, P.A.G.M., H.A. Zanting and A.M.C. Lemmens, 2000. Estimation of water pollution sources in Lake Victoria, East Africa: Application and elaboration of the rapid assessment methodology. J. Environ. Manage., 58: 235-248. DOI: $10.1006 /$ jema.2000.0322

Singh, A., 1989. Review article digital change detection techniques using remotely-sensed data. Int. J. Remote Sens., 10: 989-1003. DOI: $10.1080 / 01431168908903939$

Sobonn, R., E.C. Paringit and K. Nadaoka, 2007. Monitoring and assessing the effects of land use/land cover on water quality of Tonle Sap Lake, Cambodia, by spatial data analysis and remote sensing approach.

Sovann, C., I.N. Kim, S. Suthipong, S. Kok and E. Chea, 2011. A dynamic modelling approach as a decisionmaking tool for assess hydrologic and water quality pressures on natural wetlands treatment of wastewater in Phnom Penh, Cambodia.

Van der Hoek, W., V.T. Anh, P.D. Cam, C. Vicheth and A. Dalsgaard, 2005. Skin diseases among people using urban wastewater in Phnom Penh.

Webster, R., 1985. Quantitative Spatial Analysis of Soil in the Field. In: Advances in Soil Science, Stewart, B.A. (Ed.)., Springer, New York, ISBN-10: 978-1-4612-9559-4, pp: 1-70.

Yim, M., S. Vathna and K. Irvine, 2008. Storm and dry weather water quality characteristics in the Phnom Penh combined sewer system. Proceedings of the 6th International Symposium on Southeast Asian Water Environment, (AWE' 08), Bandung, Indonesia.

Zhang, Y., Y. Wang, Y. Wang and H. Xi, 2009. Investigating the impacts of Land Use-Land Cover (LULC) change in the Pearl River delta region on water quality in the Pearl River estuary and Hong Kong's coast. Remote Sens., 1: 1055-1064. DOI: $10.3390 / \mathrm{rs} 1041055$ 